\title{
MASYARAKAT PERAK ABAD KE-18: INTERPRETASI HISTORIS DARIPADA MISA MELAYU
}

\author{
Oleh \\ Muhammad Yusoff Hashim
}

Di dalam penjenisan hasil hasil penulisan Melayu, sejarah merupakan salah satu 'genre' daripada penghasilan tersebut. Ianya lahir di dalam bentuk lisan, juga tulisan. Misa Melayu (MM) adalah salah sebuah daripada penghasilan yang termasuk ke dalam lingkungan ini. Pengetahuan perihal wujudnya MM muncul pada tahun 1871. Maklumatnya telah diterangkan oleh W.E. Maxwell, iaitu mengenai dua buah naskhah Melayu yang ditemuinya di Perak.' Selepas itu, MM mulalah mendapat perhatian pengkaji dan peminat kesusasteraan Melayu.

Terdapat beberapa buah naskhah MM di London dan Leiden, The Netherlands. ${ }^{2}$ Pada tahun 1919, R.O. Winstedt telah menyelenggarakan $\mathrm{MM}$ di dalam sebuah penerbitannya dan kelihatan amat memanfaatkan ahli sejarah dan perujuk sastera. ${ }^{3}$

Edisi Winstedt ini telah diulang cetak beberapa kali dan kali akhir ianya dicetak semula pada tahun 1991 di Kuala Lumpur. Penyelenggaraan ini kali pertamanya diusahakan oleh beliau setelah menyedari betapa MM penting sebagai sebuah penghasilan sejarah peribumi, tetapi diperabaikan.

Untuk beberapa tahun berikutnya, MM terus diberikan perhatian dan pengamatan, terutama dari segi persejarahan dan kesejarahannya ${ }^{4}$. Pada tahun 1983, MM diperkatakan pula dengan menggunakan

"William E. Maxwell, "Notes on Two Perak Manuscripts", dalam ISBRAS, II, Disember 1878, 183-93.

2Di Perpustakaan Utana Universiti Malaya, salinan mikrofilem dari Naskhah 48165 dari Perpustakaan Universiti London (SOAS), ianya dijuduli sebagai Salasilah Perak. 'Rujuk R.O. Winstedt, (ed.), Misa Melayu oleh Raja Chulan, Penerbit Pustaka Antara. Kuala Lumpur, 1968.

"William E. Maxwell, "The Dutch in Perak", dalam JSBRAS, X, Disember 1882. Aim. 245-268; dan William E. Maxwell, "History of Perak from natuve Sources". dalam JSBRAS, IX, 1884, 85.108. 
pemkekatan stumkturalisme, ditinjau dari sudut penghasilan sebuah kat ya sistcta. juga meturtusi kacdalı kajibandeng hagi mempetjelaskan etti penulisan MM. Walaupun hal ini herupa suatu percuhaan awalan saja. namun penclekalan dan kacelah yang digunakan terhadap penganalisisan MM merupakan suatu usaha yang menarik.'

MM dikarang olch Raja ('hulan (Kaja Kechil Besar) ibnu Raja Abdul Hamid ibnu Yang Dipertuan Muda Raja Mansur, Bcliau adalah seorang kerabat diraja Perak. 1)i dalam sebuah datipada naskhah MM yang diketemui hal ini memang disebut dengan jelas. lanya bukanlah dakwaan Raja Chulan sendiri, malah adalah suatu kenyataan tulisan yang disisipkan oleh seorang penyalin naskhah tersebut yang sesungguhnya mengetahui bahawa kaja Chulanlah yang mengarang teks ini. Dikatakan olehnya bahawa; "... ialah yang mengarang hikayat ini (MM) pada zaman itu. Dan ialah yang bijak pada mengarang hikayat dan ikatan-ikatan".

\section{Kandungan MM}

Pada asasnya MM mengandungi riwayat perihal sejarah Perak mulai pemerintahan Marhum Jalilullah (Sultan Muzaftar Shah II). Baginda memerintah dari tahun 1636 hingga 1653. Riwayat ini dilanjutkan sehingga ke zaman pemerintahan Sultan Alauddin Shah Iskandar Muda (Marhum Sulong) yang memerintah Perak dari tahun 1773 hinggalah $1786 .^{\circ}$

Walaupun nampaknya MM dimulakan dengan pengriwayatan Perak sejak dekad ketiga awal abad ke 17 sehinggalah ke dekad kedua penghujung abad ke18, namun, hampir keseluruhan kandungan MM menumpukan perhatian kepada seorang tokoh kerabat iaitulah Sultan Iskandar Zulkarnain yang dimulai dengan kisah baginda pada tahun-tahun 1740 an sehinggalah ke tarikh kemangkatan baginda pada tahun 1764 .

Dengan mengenepikan aspek-aspek filologi di dalam rencana ini teks MM yang dirujuk di sini ialah dari edisi 1919, hasil penyelenggaraan R.O.Winstedt. Tidak termasuk salasilah dan riwayat raja-raja Perak yang hidup mendahului Sultan Iskandar

'Sulastin Sutrisno, "Misa Melayu: Its Literary and Historical Values", dalan Taufik 'Sulastin Sutrisno, "Misa Melayu: Its Literary and Historical Values", dalam Takarta,
Ahelullah (ed.). Papers of the Fourth Indonesia-Dutch History Conference, Yogyation
$22-24$ Julai 1983. 22.24 Julai 1983.
"R.O. Winstedt dan R.J. Wilkinson, A History of Perak, MBRAS. Reprint No.3, 1914.
132. 
(Marhum Kaharullah) dan riwayat dua orang raja Perak yang memerintah selepasnya, pengkisahan tentang Sultan Iskandar sebenarnya menjangkau hampir $96.4 \%$ daripada seluruh riwayat MM. Lima orang raja Perak yang disebutkan mendahului pemerintahan Sultan Iskandar Zulkarnain ialah;

Sultan Muzaffar Shah II (Marhum Jalilullah)

Sultan Mahmud Shah (Marhum Besar)

Sultan Alauddin Mughayyat Syah (Marhum Sulong)

Sultan Muzaffar Syah III (Marhum Hajiullah)

Sultan Muhammad Syah (Marhum Aminullah)

Dua orang raja yang disebutkan sebagai pemerintah Perak selepas baginda pula ialah:

Sultan Mahmud Syah (Marhum Muda)

Sultan Alauddin Mansur Syah Iskandar Muda (Marhum Sulong)

Oleh itu, semua raja-raja Melayu yang dinyatakan ialah seramai lapan orang. Mereka semua mentakhtai kerajaan Perak. Dengan berpaut teguh kepada tradisi dan konvensi pensejarahan Melayu yang lain di rantau ini, seperti biasanya, tahap-tahap pemerintahana raja dan peristiwa secara berturutan dijadikan induk dan dasar bagi segala dan semua perkembangan riwayat MM dari awal hingga akhir. Tahap dan urutan pemerintahan raja-raja menjadi stereng yang memandu arah perkembangan dan proses pensejarahan Perak sepanjang abad ke-18 tadi. Dengan bersifat demikian, maka MM adalah sebuah karya sejarah yang bercorak elitis menggambarkan, “... interplay of personalities at the highest level".?

Pada umumnya masyarakat Melayu kalangan inilah yang mendasari riwayatnya, dengan imbasan kalangan yang luar dari istana, iaitu rakyat biasa. Terdapat tiga bahagian besar riwayat MM, iaitu:

(a) Bahagian induk yang ditulis zaman atau semasa dengan hidupnya Raja Chulan, sehingga kemangkatan Sultan Iskandar.

\footnotetext{
- Bandingkan kesamaan riwayat dalam Syaur Perung Mengkusar (Eulısı C. Skinner, 1963), Syair Sultan Maulana (Edisi Mulıammad Yusoff Hashum 1980), Hikayat Acheh (Edisi T. Iskandar 1958) dan Tuhfat al-Nafis (Edisı Virginia Matheson. 1982).
} 
(b) Bahagian syair yang mengisahkan pelayaran Sultan Iskandar di Perak.

(c) Bahagian ketiga, tentang pemerintahan dua orang sul$\tan$ selepas Sultan Iskandar.

Ketiga-tiga bahagian ini digabungkan menjadi teks dan sebuah penulisan lengkap pada tahun 1252 Hijrah (1836). Kemudian, disambung sedikit bahagian hujungnya, iaitu tentang lagu-lagu gendang nobat Perak, pada tahun 1326 Hijrah (1908).

Oleh itu. MM adalah sebuah penulisan yang lengkap dan padat. Ia menggambarkan pensejarahan masyarakat peribumi. Ia juga memberikan kita maklumat dan butiran tentang sejarah Perak, dari awal hingga hampir ke penghujung abad ke-18.

Sebagai sebuah hasil penulisan, MM mempunyai strukturnya tersendiri dan mengandungi falsafah tentang pensejarahannya yang tersendiri pula. Coraknya yang masih patuh kepada konvensi dan tradisi penulisan sejarah Melayu yang segenre dengannya, menyebabkan ia menjadi sebuah hasil tumpuan istana dengan menumpukan ketokohan Sultan Iskandar Zulkarnain, barangkali setaraf dengan pengarangan Hikayat Acheh yang menjurus keketokohan Sultan Iskandar Musa Mahkota Alam Syah (16061637) di Acheh. Oleh itu, MM dikarang bukan tanpa matlamat dan sebab, bukan tanpa maksud dan tujuan. Untuk meminjam kalimat C.C. Berg tentang tradisi babad dan kidung dalam tujuan pensejarahan Jawa Kuno, "... for the glorification of king or kings" dan mencemerlangkan Sultan Iskandar Zulkarnain dan beberapa tokoh sultan Perak yang lain.

Serangkap kata pengakuan Raja Chulan sendiri dalam syairnya;

\author{
Petik persembahkan suatu rencana \\ mendapat hadrat yang amat ghana ... \\ Tuan sultan raja yang ghana \\ mendapat hakikat yang amat sempurna \\ arif sangat bijak laksana \\ mengetahui ilmu Tuhan Rabbana.
}

- C.C. Betg. "The Javanese Picture of the Past", dalain Soedjatnokko, et. al. (ed.). An Intraduction to Indanesican Histonugraphy. Lituaca, 1965, 87.117. 


\section{Daulat Tuanku Duli Mahkota}

limpah karar di atas takhta

patik persembahkan suatu cerita

di Tanjung Putus membangunkan kota.

Selain sanjungan terhadap "penaung"nya dilakukan oleh Raja Chulan bagi pengarangan MM, ia juga dirujuk dan disandarkan kepada bukti dan hakikat sejarah yang sebenarnaya telah terjadi di Perak. Bukan mitos secara bayangan pengarangan dan tidak pula mitos secara tegas mengenai salasilah dan asal-usul rajaraja Perak, ${ }^{9}$ seperti yang kerap terdapat dalam pengarangan karyakarya Melayu yang sekerabat dengan MM.

Pada tahun 1978, Barbara Watson Andaya cuba menguji kesahihan MM dengan merujuk pada sumber sezaman Belanda daripada siri Koloniaal Archief, tentang laporan-laporan rasmi pegawai-pegawai Belanda (yang datang ke Perak untuk tujuan perdagangan bijih timah) kepada kantuur VOC di Melaka dan Betawi (Batavia). Barbara mengulas tentang kandungan MM" ... a chronicle which provides a perfect compliment to the VOC documents" 10

Walau bagaimanapun, perbezaan corak maklumat dan butiran antara MM dengan laporan VOC ialah terletak kepada maksud dan matlamat kedua-duanya dihasilkan, dan sudut pandangan antara kedua-duanya. MM lebih bercorak "first hand knowleedge". Penulisnya menyaksikan, merasai, melibatkan diri secara langsung dengan perkembangan sejarah Perak sendiri, memahami adat resam, mengkongsi etos dan pandangan hidup yang barangkali serupa dengan masyarakat Melayu Perak yang ditulisnya, walaupun kecondongannya ke arah "penaung"nya mungkin ada. Laporan VOC pula dibuat menerusi pandangan "orang luar" yang bukan Melayu, yang datang ke Perak semata-mata kerana matlamat dagang dan ekonomi. Kalangan Melayu yang memusuhi mereka tidak akan menerima sanjungan. Raja Chulan membenci mereka, contohnya dengan ungkapan "holanda kutuk","orang celaka". ",

\footnotetext{
'Mitos tentang asal-usul raja-raja Perak terdapat dalam bahagian mukacliniah Misa Melayu apabila dikatakan salasilah raja-raja Perak dikastkan dengan Iskandlar Zulkarnain, Raja Nusyirwan Adit, Raja Suran dan Bukit Seguntang Mahamuru. Lihat R.O. Winstedt (ed.),
Misa Melayu, 21. 10Barbara Watson Andaya, Perak The Abme of Grace. A Study of An Etghteenth-Century
Malay State, Oxford University Press. Kuala Lumpur, 1979,21 "Rujuk Misa Melayu,154-155.
} 
Walaupun demikian. kedua-duanya bermanfaat untuk penulisan sejarah setempat. MM boleh menjadi asas dan wadah penulisan sejarah abad ke-18 jika dilihat dari ciri-ciri kesejatian dan keperibumiannya, malah sahih pula maklumat dan butirannya setelah diuji. Laporan VOC pula boleh membekalkan butir dan perihal yang terperinci bagi melengkapkan butiran MM, untuk memperbina fakta yang sahih dan tepat tentang berbagai-bagai aspek dan institusi masyarakat Perak sepanjang abad yang dijangkaui.

\section{Kandungan Yang Membina Riwayat Misa Melayu}

Pada umumnya, MM memperlihatkan suatu corak struktur tentang kerajaan negeri Perak dan perihal bagaimana struktur ini beroperasi dan dilaksanakan. Malah apabila meneliti rangka kerja bagi komposisi MM, faktor inilah yang mendasari seluruh aktiviti masyarakat dan proses perkembangan sejarah Perak. ditinjau dari segi konsepsi pengarangan MM yang lebih bermakna lagi. Dengan raja yang memerintah berdiri sebagai paksi, disekelilingnyalah operasi tentang berkerajaan tadi berlegar. Segala titik bengik masyarakat yang berkait dengan hal ehwal berpolitik. perihal aktiviti ekonomi, perlaksanaan dan amalan adat-istiadat, soal peperangan, hal yang menyangkut komplot di kalangan mereka yang memegang wibawa dan/atau kuasa pemerintahan serta mereka yang berpotensi dalam hal ini, episod-episod remeh tetapi amat berfungsi yang menyangkut 'intrique' di kalangan mereka yang memegang wibawa dan/atau kuasa pemerintahan serta mereka yang berpotensi di dalam hal yang memperbina riwayat MM (seperti kelahiran sesuatu tokoh, perkahwinan, pelayaran dan pengembaraan) harus dikaitkan secara langsung atau tidak dengan kalangan istana atau pun khususnya kalangan yang memegang kuasa dan memerintah, raja atau sultan.

Semua anasir ini menjadi rempah-ratus utama bagi menyokong dan menegakkan kedaulatan seseorang raja atau sultan Perak yang sedang bertakhta. Suasana bandar yang hiruk-pikuk akibat dikunjungi para dagang dan santeri dengan anekaragam jamuan. peperangan yang sentiasa dimenangi oleh pihak yang memerintah. prinsip dan kaedah penggantian seorang raja (terutama pada waktu upacara permakaman raja yang telah mangkat) yang tidak pernah menimbulkan sebarang konflik (sedangkan realiti yang sering terjadi adalah disebaliknya), semuanya adalah menjadi unsur riwayat yang menyumbang bagi menegakkan kedaulatan tadi. Ini terjadi demikian, sebab begitu dan itulah caranya Raja Chulan 
melihat dan mempersepsi ertian sejarah bagi negeri Perak abad ke-17, barangkali berbeza daripada ertian sejarah pada masamasa sebelum atau selepasnya. Anasir-anasir tadi dianggapnya ideal bagi tujuan, “... reshaping of historical reality" 12 mengikut pengertiannya sendiri.

Oleh itu, pada tahap-tahap pemerintahan raja-raja Perak dari awal abad ke-18 hingga tahun 1780-an, pengalaman-pengalaman yang bermotifkan hal-ehwal yang tersebut menjadi unsur dan faktor pembinaan dalam proses perkembangan sejarahnya. Secara terperinci, ia dapat dilihat seperti berikut:

a. Dari tahun 1636 hingga tahun 1720 tradisi penggantian sultan mengikut prinsip "warisan negeri" (anak-anak raja).

b. Selepas tahun 1720-an, bermula dengan pemerintahan Sultan Muzaffar Syah, terjadi berbagai-bagai konflik politik yang amat mencabar. Ia melibatkan struktur dalaman dalam proses berkerajaan Perak, memancarkan suatu unsur dinamik yang amat menarik di dalam pensejarahan peribuminya. Unsur kedinamikan ini memberikan kesan sejarah seterusnya dalam pensejarahan tadi, hingga ke penghujung abad ke-19. Antara konflik yang menonjol ini, ialah:

(i) Cabar-mencabar dalam hal pengwarisan takhta. Akibatnya, ketika pemerintahan Sultan Muzaffar Syah (1728-1744), Perak terbahagi dua kerana wibawa baginda dicabar oleh adiknya, Sultan Muhammad Syah.

(ii) Isu"huru-hara di dalam negeri Perak ini", seperti yang terdapat dalam $\mathrm{MM}^{13}$, diakhiri secara ikhtiar politik juga. Tokoh menonjol yang memainkan peranannya ialah Raja Muda Iskandar Zulkarnain, yang kemudian bergelar Sultan mulai tahun 1754.

c. Dewasa Sultan Iskandar memerintah, timbul pula isu politik yang menarik, iaitu terjadi "peranjakan kuasa" daripada kuasa dan wibawa politik yang sebelum itu banyak dipegang dan ditentukan oleh para pembesar dan menteri, kepada pihak Sultan yang memerintah.

${ }^{12}$ Anthony Reid \& Lance Castles (et.). Pre-Colonial Stute Systems in Sontheast Asia. Monograf MBRAS, No. 6, 1975, him. 24.

'Bujuk Misu Melayu, 22 
Terjadi juga pada masanya (ketika menjawat Raja Muda, tetapi telah pun diberikan wibawa memerintah) ${ }^{14}$ perubahan sistem pembesar, apabila jawatan dan fungsi Bendahara yang secara temurun sejak abad ke-16 dipegang oleh orang "luaran" sekarang diberikan pula taraf "kedirajaan", lalu dipegang oleh kalangan "dalam", dan menjadi Raja Bendahara. Ia diinstitusikandan menjadi tokoh ketiga dalam sistem penggantian raja, kepada sesiapa waris negeri yang memegangnya. Pada abad ke-19, perubahan sistem pembesar seperti ini sebenarnya memberikan pengaruh kepada sistem pembesar di Pahang dan Selangor. Sultan Iskandar juga sedar bahawa corak kuasa dalam sistem berkerajaan dengan mana beberapa orang besar amat berpengaruh dan berkuasa di daerah masing-masing, menjadi faktor penghalang bagi mencipta ketunggalan wibawa pemerintahan dan penyatuan kuasa Perak. Oleh itu, hanya mereka yang taat dan setia kepada rejim baru Sultan Iskandar sahaja dikekalkan. Pembesar utama yang empat, Datuk Bendahara, Orang Kaya Besar, Temenggung dan Menteri diberhentikan, kerana "... tiada ia mengikut", dakwa MM. ${ }^{15}$

Perkahwinan Raja Muda Iskandar dengan Puteri Budak Rasul. sepupunya, iaitu puteri Sultan Muzaffar Syah, tidak harus dilihat dari segi pengistiadatan dan kebudayaan Melayu semata-mata, malah patut dikaitkan dengan proses perpolitikan Perak sendiri. Perkahwinan politik seperti ini bukan sahaja menghubungkan secara keluarga dua pihak yang berbalah dalam hal-ehwal politik, malah merupakan muslihat perpolitikan yang cukup halus, tetapi berkesan, daripada corak politik pemecahan kepada politik penyatuan atau gabungan. Hal demikian mengingatkan kita tentang muslihat politik yang dilakukan oleh Sultan Muzaffar Syah Melaka (abad ke-15) bagi menggabungkan tenaga Melayu yang berpecah, iaitu penyokong Penghulu Bendahari dengan penyokong Bendahara, dengan menggunakan Tun Kudu, sebagai unsur "penggabungan" tadi. ${ }^{16}$

"Kata teks ini, "Maka Raja Mudalah (Raja Iskandar) yang memerintah di dalam neger! Perak ini dan yang diikut turutlah akan segala orang besar-besar. dan anak raja-raja. maka terserahlah kepada Raja Muda", rujuk Misa Melayu. 26.

isembesar-pembesar ini dilantik oleh Sultan Muzaffar Syah, ketika hersemayam di Kuala Kangsar. Pembesar-penibesar yang dilantik kerana menjadi penyokong Raja Muda Iskandar ialah Megat Pendia sebagai Bendalara, Tan Marasin sebagai Orang Kaya Besar, Tan Bantan sebagai Temenggung dan Orang Kaya Syariff Hussein sebagai Mentert. rujuk Misa Melayu, 26.

'W.G.Shellabear (ed.), Sejarah Melayu, Singapura, 1961. 94-95. 
Keholehan istimewa Sultan Iskandar dalam herkerajian menyebabkan warna-warna baru muncul di dalam pensejarahan Perak. Di antaranya ialah:

i) Tampilnya seorang tokoh politik yang amat berkarisme dan berkalebar dalam pemerintahan Perak pada abad ke- 18 .

ii) Terjadinya perubahan dalam struktur dalaman di kalangan pemegang-pemegang kuasa di peringkat pusal dan daerah.

iii) Peningkatan sumber pendapatan negeri akihat pemulihan semula hubungan dagang antara Perak dengan Belanda dan bertambahnya eksport gajah Perak ke luar negeri.

d. Proses perubahan dan fenomena pensejarahan abad ke-18 tidak hanya terhad di peringkat masalah dalam negeri saja, tetapi termasuk juga hal-ehwal luar negeri. Ini dapat dilihat dengan penampilan episod peperangan antara kalangan Melayu Minangkahau yang diketuai oleh Sultan Berkabat ibn Raja Kechil, Siak, dengan Melayu Perak. Walaupun pihak penyerang kecundang, namun suasana politik makin meruncing akibat penglibatan langsung kalangan Melayu Bugis pula, dari mana pemerintah Perak yang satu lagi, Sultan Muhammad Syah, ayahanda Raja Muda Iskandar yang bersemayam di bahagian hilir Perak, memperoleh bantuan ketenteraan.

e. Hubungan politik antara Perak dengan Bugis menyebabkan kalangan pemerintah Bugis di Selangor pada tahun 177() (iaitu Raja Lumu) datang ke Perak, lalu Sultan Mahmud Syah ibn Sultan Muhammad Syah, menobati dan mendaulati baginda sebagai Sul$\tan$ Salehuddin, Yang Dipertuan Selangor.

f. Kisah Raja Alam, anak saudara Sultan Muzaffar yang berkomplot dengan kalangan Melayu Haru dan Bugis; “... yang jahat-jahat”, dan "yang buruk-buruk", kata MM, "untuk menentang kewibawaan pemerintah. Penentangan mereka menyebahkan pemerintah Perak dan Raja Muda Iskandar terpaksa berhubungan dengan Belanda di Melaka. Mereka berjaya mematahkan penentangan tersebut dan Raja Alam dipenjarakan di Melaka. Hubungan ekonomi dagang antara Perak dengan Belanda, secara tidak langsung mengesani dan memanfaatkan pula masalah politik Perak. 
Inilah antara isu pokok yang mendasari pembinaan riwayat MM yang meliputi bidang politik, ekonomi dan kebudayaan lsu-isu ini diperlengkapi lagi dengan pemaparan hal-hal sejarah yang lain seperti:

(a) Sambutan adat-istiadat di dalam perkahwinan, pertabalan. permakaman, bertuba ikan di sungai dengan raja sendiri terlibat. Isu kebudayaan ini sebenarnya mengaitkan soal pemerintahan danpentadbiran kerajaan. Contohnya, pada masa diadakan istiadat menuba ikan di sungai Perak, raja yang memerintah sekaligus melihat keadaan rakyat yang di bawah perintahnya.

(b) Siri-siri kedatangan pedagang atau pegawai Belanda ke Perak. Raja Chulan menempelak mereka mungkin kerana mereka memonopoli pembelian bijih dari Perak. Mereka bukan setakat untuk "membeli" bijih di situ, malah menambahkan lagi pendapatan negeri daripada penjualan bijih. Sultan Muzaffar sendiri dikatakan oleh MM menjadi teramat kaya dengan perolehan hasil ini; “adapun padazaman itu, akan Sultan Muzaffar Syah itu, terlalu kayanya, terlebih daripada ayahanda baginda yang telah lalu ${ }^{18}$ Ia adalah amalan langsung Prinsip Dutch Treaty System Kompeni VOC di rantau ini, keatas Perak khususnya. Dokumen-dokumen perjanjian yang termaktub membuktikan hakikat ini. ${ }^{19}$

(c) Sultan sendiri terlibat dalam aktiviti dagang. Sultan Perak mengirimkan Tambi Kecil ke India bagi menggalakkan para saudagar India membeli gajah Perak daripada baginda sendiri.

(d) Kerancakan aktiviti ekonomi menyebabkan Perak didiami berbagai-bagai suku bangsa seperti Melayu, dan kalangan berbagai-bagai sukunya, Belanda, Cina dan India, memancarkin sebuah masyarakat yang bercorak kosmpolitan. Kerapatan hubungan antara dan kalangan sesama suku dan kaum masyarakal ini dipancarkan menerusi episod persembahan berbagai-bagai

\footnotetext{
12 Ibid., 26. Ini merupakan sisipan yang dilakukan oleh penyalin terkemuitian Mtsed Melayu yang terdapat pada salah sebuah naskhahnya, bukan naskliah penyeicukg atsath
R.O. Winstedt.

"Rujuk contoh dokumen perjanjian (kontrak) abad ke-18, antara $V(X)$ dengan kerajaal Perak pacla Lampiran I tencana ins.
} 
aneka pesta ketika menyambut istiadat perkahwinan Sultan Iskandar dengan puteri Budak Rasul, selama tujuh belas hari dan malam.

(e) Pembangunan negeri,disebut sebagai;“....membangunkan negeri di Pulau Cempaka Sari”, ${ }^{20}$ walaupun bukan bermakna dalam konteks pembangunan infrastruktur seperti yang difahamkan pada masa ini, ia dimaksudkan sebagai lambang keamanan, kestabilan politik dan ketinggian daulat raja yang memerintah. Yang disebutkan MMialah semasapemerintahan Sultan Iskandar diperbina sebuah mahligai yang amat unik setinggi tujuh tingkat, membina masjid-masjid, penggunaan berbagai-bagai alat dan senjata peperangan seperti lela, pemuras, rentaka, lembing, keris, meriam, istinggar dan senapang, sertapenggunaan berbagaibagai peralatan budaya yang secara langsung menyokong kedaulatan tadi seperti gong, gendang, serunai, nafiri, ceracap, herabab, bangsi, biola dan rebana.

Semua riwayat ini merupakan "original history" (untuk meminjam istilah Hegel). Tetapi sekiranya kita melihat MM yang hakiki, nyatalah bahawa hanya rangka-rangka dasar yang digunakan bagi memaparkan pensejarahan Perak pada abad ke-18. Rakyat biasa dan bawahan dapat melihat rangka-rangka dasar tersebut dengan mata, mudah difahamkan, sama-sama menyaksikan, juga sama-sama mengalaminya, seperti sambutan istiadat, peperangan dan perniagaan. Tetapi, Raja Chulan, seperti juga ahli sejarah Melayu yang sezaman dengannya, tidak menyelami hakikat dan tenaga-tenaga tertentu yang sebenarnya menjadi faktor dasar menggerakkan proses pensejarahan tadi. Ia lebih membentangkan kesan dan akibat daripada pergerakan tersebut, bukan musabab yang melatarbelakangi kesan dan akibat pensejarahan tadi. Oleh itu, untuk memahami pensejarahan MM dan melihatkannya sebagai sumber "reflective" bagi abad ke-18, serta melihat terjadinya proses serta perubahan masyarakat pada abad tersebut, latar belakang sejarah dan sosiobudaya Perak itulah yang harus terlebih dahulu difahamkan. 


\section{Latar belakang Sejarah dan Sosiobudaya}

Faktor geografi dan topografi sering mempengaruhi corak dan perkembangan sejarah sesebuah kawasan. Apabila kita memperkatakan pensejarahan Malaysia umpamanya, faktor sungai dan saliran sungai kerap menjadi salah satu faktor asas yang mempengaruhi fenomena dan corak sejarahnya. Tidak lerkecuali juga dengan pensejarahan Perak. Sungai Perak sendiri membekalkan berbagai-bagai unsur sejarah, terutama hal-hal yang berkait dengan kewujudan serta pelaksanaan kerajaan serta kuasa dan kewibawaan dalam pemerintahan. Abad ke-18 menentukan sumber kuasa dan wibawa di mana seseorang raja bersemayam di kawasan-kawasan tertentu sepanjang sungai tersebut. Contohnya di Indera Sakti. Pulau Tiga, Berahman Indera.

Bentuk muka bumi Perak menyebabkan ia terbahagi secara fizikal kep̧ada dua kawasan. iaitu hulu Perak dan hilir Perak. Adanya jeram yang amat banyak di sepanjang sungai, hutan yang tebal, ketiadaan jalan-jalan yang mudah untuk dilalui." kawasan hilir yang dipenuhi lembah dan berbukit-bukit, kawasan hulu pula yang berbukit-bukau, menyebabkan perhubungan antarat dua bahagian kawasan yang terletak di sebuah negeri ini cukup menyulitkan. Sungai sering disebut sebagai jalan perhubungan dan laluan yang paling asas di Perak, tetapi masalah yang diberikan olehnya, amat jarang diperkatakan. Arah ke hulu sungainya semakin sempit dan bengkang-bengkok. Hubungan hulu dengan hilir sering terputus apabila kemarau. Pada abad ke-18, pernah disebut hahawa perjalanan ke hilir dari hulu mengambil masa dua minggu melalui sungai, dan kira-kira 20 hari mengikut jalan darat.:"

Masalah hubungan kerana faktor geografi ini memberikan kesan secara langsung pula dalam soal pelaksanaan dan amalan wibawa serta bidang kuasa pemerintah. F.F. Laidlaw umpatmanya pernah mengembara dan mengadakan ekspedisi ke kawasan hulu Perak pada tahun 1899. Menurutnya, soal perhubungan yalng

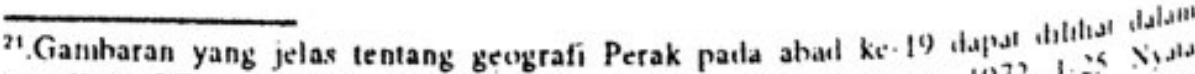

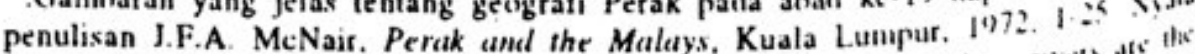

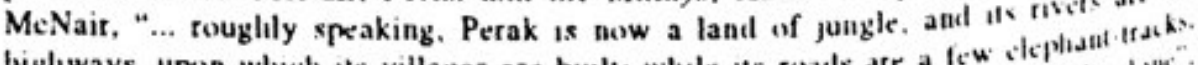

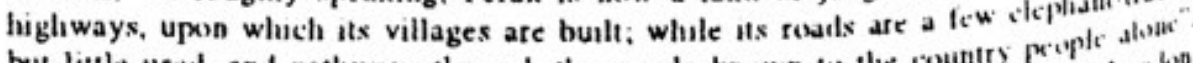

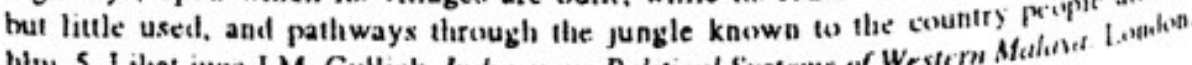

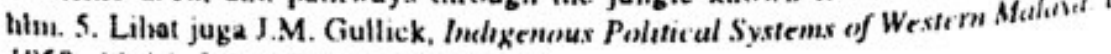
1958. 11-14. Lihat Peta 1 rencana int.

12. A.A. Wernally's Day Register, 17 Septemher 1769.
} 
amat menyukarkan di kawasan ini memungkinkan seorang ketua Melayu di situ membentuk dan mewujudkan kuasa serta pengawalannya sendiri; pemberontakan dengan mudah holch dilakukan; seorang pesalah holeh herlindung, dan lari daripada keadilan.23

Akibatnya, arahan dan perlaksanaan wibawa serta keberkesanan kuasa yang selalunya datang dari kawasan tempat raja hersemayam. bukan merupakan suatu perkara yang mudah. Ini ditambah pula oleh tradisi tempatan bahawa kawasan hululah yang mengasal usulkan negeri Perak. Soal kesempadanan juga menumitkan. Kawasankawasan ini pada hakikatnya lebih menghampiri kawasan selatan Patani dan Kedah. ()leh itu, isu taat setia penduduk dan pembesar kawasan ini terhadap raja yang memerintah. tetapi herada puluhan kilometer ke hilir. sering menjadi soalan yang tidak terjawah. Satu kecenderungan politik sekarang timbul. Ada menteri dan pembesar yang bukan kerabat mendakwa boleh menjadi raja atau sultan. Suatu sumber pada abad ke-19 menychut Menteri larut sebagai mendakwa dirinya, “... the most powertul man .... According to Perak custom, if I were a common lamplighter and had only men to back me, I might be made sultan tomorrow". ${ }^{24}$

"Powerful" di sini boleh diertikan sebagai kuat dan kukuh daripada segi milikan ekonomi dan mempunyai pengikut yang ramai. Tetapi faktor "penyekat" yang paling pokok daripada terjadi dan terlaksananya kecenderungan politik seperti ini ialah keturunan dan salasilah, iaitu antara yang kerabat atau anak raja yang ditradisikan sebagai waris negeri, dengan yang bukan kerabat.

Milikan ekononi sering dirujuk kepada sumber pendapatan dan hasil Perak pada abad ke-18, iaitu bijih timah dan kegiatan perniagaan gajah dengan India. ${ }^{25}$ Dari segi teori, daulat bagi seseorang raja dirujuk daripada keturunan (secara kepercayaan dan mitos Bukit Seguntang, Palembang. menerusi Kesultanan Melaka dan kedaulatan dari Pagar Ruyung, Minangkabau). Pemilikan daulat ditentukan oleh faktor kelahiran dan taraf sosial. Melaluinyalah

2SF.F Laidlaw. "Travels in Kelantan. Trengganu and Upper Perak. I 899", dalam IMBRAS. XXIV,vi, 1953, 189; W.E.. Maxwell, "A Journey on Foot to lle Patan Frontet in 1876", dalam IMBRAS, No. IX, Jun 1882, 2-3.

"Perak Enquiry Papers. Vol. II. Series XXIII, September 1876, dipetik wleh Keul \& Castle (cot.) Pre-Ciolemual State Systems, 28.

2S ihat buku Barhara Watson Amlaya, op.cit., 1979, Bah 111 dan Bah IV. I. Hat juga lakaran Peta 2 dan 3 rencana inı mengenai kawasan-kawasan perlenubougan hiph Iunah di bahagian hulu dan hilir Perak ahad ke-18. 


\section{Jurnal Sijuruh}

wibawa spiritual dan duniawi dilaksanakan terhadap rakyat. Tetapi dari segi realiti, faktor dasar perlaksanaan wibawa dan kuasa ini terletak pada taraf sumber penghasilan dan milikan ekonomi yang ada padanya. Malah pada abad ke-18, milikan ekonomilah yang mendasari kekuatan politik. Milikan ekonomi yang kukuh dapat menyekat cita-cita politik beberapa orang pembesar pada abad itu. Tetapi pada abad ke-19. keadaan menjadi di sebaliknya. Kesannya, berlakulah perpecahan dalam kuasa memerintah.

Perlaksanaan bidang kuasa pemerintahan bagi sebuah kawasan yang lebih kurang lapan ribu batu persegi luasnya, bukanlah perkara yang tidak sukar, jika tanpa sokongan dan bantuan para menteri dan pembesar daerah. Menerusi kalangan inilah saja wibawa dan kuasa tadi dapat disalurkan kepada rakyat. Sekatan resam dan keturunan pula menyebabkan pembesar dan menteri yang kaya raya cuba melemahkan sultan dan menyokong waris negeri, terutama Raja Muda, bagi merebut takhta kerajaan.

Untuk menguasai dan mengawal kawasan-kawasan yang berpotensi ekonomi juga bukanlah suatu hal yang mudah, akibat masalah geografi tadi. Tetapi pada abad ke 18, dengan adanya siri-siri kontrak penjualan bijih antara Perak dengan VOC, rajaraja Perak menjadi cukup kaya, tidak dapat ditandingi oleh para pembesar lain.

Sekarang. pergeseran politik yang sering meletus ialah bukan antara raja dengan pembesar, tetapi antara raja dengan Raja Muda. Sepanjang tahun 1806 hingga tahun 1871 isu inilah yang menegangi politik Perak. ${ }^{20}$ Mulai tahun 1773 hingga tahun 1792 Raja Muda Ahmaddin (adinda Sultan Alauddin) disebut sumber Belanda sebagai tokoh yang amat berpengaruh dan berwibawa di Perak. Tetapi apabila menjadi raja, baginda hilang sokongan daripada anak raja dan pembesar negeri. Waris negeri bergaduh sesama mereka untuk berkuasa. Perlaksanaan wibawa pemerintah menjadi cukup tidak berkesan.

Hakikat sejarah dan proses pensejarahan yang terjadi ini menimbulkan akibat dan tindak-tanduk susulan oleh para pemegang kuasa dan wibawa Perak serta memberikan kesan terhadap pensejarahan Perak itu sendiri. Faktor-faktor inilah yang pada umumnya mendasari dan melatarbelakangi riwayat sejarah yang membina keseluruhan kandungan MM. Antaranya yang ditampilkan

:Khoo Kay Kiin, The Westem Malay States, 1850.1873, Kuala L.umpur. 1972, 23. 
(a) Perak terbahagi dua. Bahagian hulu diperintah oleh Sultan Muzaffar Syah, bahagian hilir diperintah oleh adiknya, Sultan Muhammad Syah. Sempadan bidang kuasa ialah di Pacat.

(b) Raja Muda Iskandar ibnu Sultan Muhammad menyedari hakikat ini dan tenaga-tenaga politik yang bergerak di belakang, lalu bertindak secara politik juga. Kepadanya, "negeri sebuah, raja dua" adalah mustahil. Baginda menyatukan semula hulu dan hilir. Walaupun Sultan Muzaffar terus bertakhta tetapi kuasa dan wibawa pemerintahan terletak di tangan Raja Muda, “... tetaplah Sultan Muzaffar Syah pula di atas takhta kerajaan, diperintahkan oleh anakanda baginda Raja Muda", kata MM.

(c) Pembesar-pembesar utama yang empat yang diragukan kesetiaannya dipecat, lalu digantikan oleh pihak yang boleh dipercayai kesetiaannya.

(d) Peranjakan kuasa yang dilakukan oleh Sultan Iskandar, iaitu daripada pembesar kepada sultan sendiri, bukan sahaja kerana karismenya, malah sebab kekayaannya. Antara inovasi pentadbiran yang dilakukan olehnya ialah melantik jawatan Raja Bendahara dan Sultan Muda kepada adiknya sendiri, sebagai imbangan kepada perlantikan Raja Muda, yang juga adiknya.

(e) Meneruskan hubungan dagang dengan Belanda, yang bukan sahaja memanfaatkan ekonomi, malah menjamin pertahanan sultan yang bersemayam di Kuala Kangsar apabila Belanda membina kubunya di Tanjung Putus.

(f) Hubungan diplomatik dengan kalangan Minangkabau dan Bugis akibat hadirnya unsur persaingan merebut takhta di kalangan waris negeri.

(g) Pada masa pemerintahan Sultan Mahmud, kerabat Bugis dari Selangor datang ke Perak untuk mendapatkan daulatnya (MM. hlm. 186-188). Ini adalah musabab politik, kerana pertama, Perak adalah jiran Selangor yang terhampir; kedua Peraklah satu-satunya kesultanan pada abad ke-18 yang terus mengekalkan pengwarisan salasilah kerabat dari Kesultanan Melaka. Oleh itu, dakwaan tentang kedaulatannya adalah wajar. Kehadiran Bugis di Perak juga menyebabkan Perak terlibat sama dalam konllik politik di Kedah. 
(h) Sultan Muzaffar dan Raja Muda Iskandar sendiri yang herangekall ke Kuala Kangsar dan Sungai Kinta untuk memungut cuk:at. Ini tentulah menghairankan. Keraguan terhadap kesetiaan para pembesar daerah tersebutlah menychahkan hal ini terjadi.

(i) Sultan Iskandar menjerat gajah di Sayung. Ini discbabkan sumber Belanda menyebut perdagangan gajah adalah monopoli diraja dan amat menguntungkan.

(j) Perkahwinan antara Sultan Iskandar dengan Puteri Budlak Kasul adalah kerana politik, sebab sumber Belanda menyebut juga bahawa puteri tersebut telah pun bertunang dengan Sultan Berkabat, tetapi telah diputuskan. Sultan Berkabat tentulah marah. lalu menyerang Bukit Gantang.

Semua contoh dasar pada riwayat tersebut bukanlah "fictional", malah sahih dan bersejarah. Hanya kaedah penyampaiannya itu sahaja yang dikarang dan dibentukkan mengikut rasa dan selera masyarakat pada abad itu. Menerusi riwayat tadi MM menerangkan secara bayangan struktur kerajaan Perak pada abad ke-18 dan kaedah struktur itu dilaksanakan. Sumber Belanda daripada laporan Ary Verbrugge menyebut, peperangan saudara dan perpecahan kerajaan pada tahun 174()-an adalah akibat percubaan Raja Muda Iskandar merampas takhta daripada pamannya, Sultan Muzaffar. Ini disebabkan adanya peluang ekonomi, sokongan para pembesar Perak dan bantuan ketenteraan kalangan Bugis dari Selangor. Peluang-peluang ini jugalah yang membolehkannya menyatukan semula Perak yang terbahagi dua itu.

\section{Kesimpulan}

Sesuai dengan sifatnya yang menumpu kepada seorang tokoh. MM adalah sebuah hasil "semi-panegyric" yang bercorak sejarah. Dengan berpusatkan ketokohan Raja Muda atau Sultan Iskandar Zulkarnain, di sekelilingnyalah proses dan perubahan sejarah Perak pada abad ke-18 itu bergerak. Malah apabila cukup yakin dengan karisme dan kebolehan kepimpinan Sultan Iskandar dalam proses perpolitikan Perak pada abad itu, maka Raja Chulan menyebutnya sebagai tokoh politik tanpa bandingan, "... tiadi siapa-siapa menyamai Raja Muda itu pada zaman itu"."7

\footnotetext{
$\overline{27 . R u j u k ~ M i s a ~ M e l a y u, ~} 33$.
} 
Dakwaannya ini dan bahagian riwayat lain yang menyokong dakwaan tersebut dirujuk kepada sumber-sumber luar dan tempatan sezaman, abad ke-18 dalam pensejarahan masyarakat dan politik Melayu di Perak, adalah pensejarahan yang cukup mencabar dan menarik.

Pensejarahan tersebut dengan sendirinya memancarkan ciriciri internal dynamics sebuah negeri dan kerajaan Melayu Semenanjung selama seabad. Antara zaman disintegration politik dan wibawa dengan zaman integration, terdapat dan berlaku banyak perubahan sejarah serta ekonomi masyarakat tersebut. Adat resam dan kebudayaan terus dikekalkan dan diamalkan. Malah dalam konteks kesinambungan, abad tersebut menjadi penghubung bagi proses dan tradisi pensejarahan abad sebelum dan selepasnya, hinggalah pada pada masa kini. Dalam aspek kedinamikannya, abad tersebut tidak statik, dan bukan merupakan "zaman gelap" dalam sejarah Perak seperti yang sering ditanggap. Malah apabila dibandingkan di antara zaman sebelum dan selepasnya. abad ke-18 adalah zaman emas di dalam pensejarahan Perak. seperti dugaan sesetengah pengkaji dan penulis sejarah..$^{2 x} \mathrm{MM}$ sendiri memancarkan hakikat ini.

\section{Lampiran 1*}

\section{Perjanjian Di antara Sultan Muzaffar dengan Syarikat Hindia Timur Belanda}

Translated Malay contract made between the King of Perak on the one side and the military lieutenant, Johan Levin Essche. on behalf of the General Netherlands Patented East India Company on the other concerning the salt trade there.

In the year of Muhammad 1164, named Jim, the seventh day of the month Rejab, Paduca Siry Sultan Malfarsa Lilulla Sul alam [Paduka Sri Sultan Muzaffar li-Allah Syah Alam], the king of Perak, has been pleased to give the contract for salt to the Honourable Company at the time that the Company's agent here was Essche, under condition that the Honourable Company give a koyan of salt annually to the Yang di Pertuan, and by this

${ }^{2}$ Haji Buyong Adil. Sejarah Perak, Kuala Lumpur, 1972, 37; Lihal juga Ismaıl Ahmad. Misa Melayu, Melaka, $1966,5-6$.

* Perkara 11-VI lanipiran ini dipetik dari Barbara Watson Andaya. Percuk: The Abende of Grace, K.Lumpur: (OUP. 1979, 40,-410. 
token no one except the Company can trade in salt. In this regard the Yang di Pertuan has come to an agreement with the Honourable Company and as a sign this paper is ratified with my seal. Tamat [The end.]

\section{Perjanjian 13 Mac 1753}

Contract and indissoluble treaty between Paduca Siry Sulthan Iskandar Sul Karney [Paduka Sri Sultan Iskandar Zulkarnain], King of Perak on the one side and Mr. Thomas Achippers, merchant and fiscal at Melaka as well as commissioner and envoy to that court on behalf of the Netherlands Patented East India Company on the other side.

1. Firstly an upright, true and indissoluble friendship and correspondence shall be maintained between His Majesty and the Netherlands Company.

2. The esteemed King promises all the tin from Perak and areas under his jurisdiction to the Honourable Company; the Company shall pay 26 ducatoons or 32 Spanish reals for the bahara of 375 Dutch lbs.

3. Besides that the Honourable Company must pay two Spanish reals only as toll for each bahara of tin.

4. The tin suppliers must bring the tin down themselves to the Company's fort, as has been done up till now. There it will be weighed with the Company's scales and weight.

5. The King shall immediately decree through his whole kingdom and to all ships that wish to go outside that they must first and foremost anchor at the Dutch fort to be inspected there, as was done after the signing of the contract in the year 1746 between the former king Sultan Muzaffar Berdaulat Syah Alam and the Honourable Company. Furthermore, according to this contract. each and every individual is obliged to deliver all his tin 10 thi Honourable Company for the fixed price. 
6. Should anyone at any time dare to smuggle tin outside without giving it to the Company, he shall, if captured, have his entire cargo contiscated. Half of this will go to the king and the other half will remain at the discretion of the Honourable Company.

7. Finally, the king promises to offer a helping hand to the Netherlands Company in all matters and to oppose and prevent all disadvantageous and dangerous plans that might at times be contemplated against the fort here by enemies of the Honourable Company and by those who wish it ill. On the other hand, the Company is bound to ensure that no subjects of His Majesty or other free merchants will becaused any hindrance or annoyance. The Company promisess to assist each and every one reasonably and justly.

Contracted in the Kingdom of Perak outside the king's dalam [residence] on the island of Misquit on the 13 March in the year after Christ's birth 1753, or in the Muslim year, named Ba [sixth year of Muslim cycle], 1166 , eight day of the month Jumada alawal in the presence of the Raja Muda, the Bendahara Besar, the Temenggong, Laksamana, Syahbandar and the Orang Kaya or nobles.

\section{Perkara Tambahan, 3 Jun 1759}

Separate articles concluded between Paduka Sri Sultan Iskandar Zulkarnain, King of Perak, on the one side, and the honourable and gallant gentleman, Jan Jansz, Visboom, military captain and also commissioner and envoy to that court on behalf of the Netherlands East India Company and thereby authorised by the most honourable and respected gentleman David Boelen, Governor and Director of the city and contract signed on the 1.3 March in the year 1753 between His Majesty and the former commissioner and envoy Mr. Thomas Schippers.

1. Regarding an elucidation of the 4 th and 5 th article of the former contract that His Gracious Majesty as well as other suppliers, shall deliver his tin to the Company fort lo be weighed there with 
the (omplany's balance and scale.

2. His Majesty, as headol the merchants, also promises that hisown ships as well as those shall be inspected and, if tin should be found in them. it shall be contiscaled as mentioned in article 6 , but the king's ship shall be given back.

Contracted and concluded in the kingdom of Perak in the king's balai at Kota l.umut in the presence of the Raja Muda, the Raja Bendahara, the Temenggong. Menteri and Maharaja l.ela on 3 June 1759 or in the Moslem year 1172, the 7 th day of the month syawal.

\section{Perjanjian, 17 Oktober 1765}

Contract and indissoluble treaty between Paduka Sieri Sulthan Mochamoct)cha [Paduka Sri Sultan Mahmud Syah], King of Perak, on the one side, and Everard Cramer, junior merchant, receiver. and licence master as well as commissioner and envoy to the court on behalf of the Netherlands Patented East India Company on the other side.

1. Firstly. an upright, true and indissoluble contidence and friendship shall be maintained between His Majesty Paduka Sri Sultan Mahmud Syah and the Netherlands East India Company.

2. To this end His Majesty promises to deliver and have delivered all the tin in his entire Country to the Company, with the exclusion of all other European and native nations and people.

3. For this the Company promises to pay $36 \mathrm{l} / 3$ guilders for $125 \mathrm{lbs}$. or $111 / 3$ round Spanish reals, and thus for the bahara of $375 \mathrm{lbs}$. 34 round Spanish reals only.

4. The King promises and undertakes to bring down all the tin that His Majesty sells to the Company to its fort, without ever deviating from this under any pretext whatsoever. At the fort His Majesty's tin will be weighed with the Company's balance, like that of all his subjects and suppliers.

5. The King promises to take all possible precautions against smuggling and to interdict and forbid any carrying out of tin on pain of contiscation of ship and cargo. 
6. And should it happen that any ill-natured person tric's to carry tin out secretly and to sell it to someone other than the Company and is captured, the ship and cargo will be confiscated immediately without any form of trial and the proceeds from this shall be divided between the king and the Company.

7. All ships (not excepting those of the king and nobles) which wish to go outside must anchor at the Dutch post to be properly inspected.

8. And in case a crewman engages in any hostile activity and excapes from the hands of the Dutch during the inspection of foreign ships, the king promises once and for all to charge his subjects to follow such evil-doers and to give them over to the resident. The Company for its part promises to do the same in such cases.

9. The King also promises that when any Europeans or European. Native or Natives in the Company's service dessert and take refuge in his kingdom, they will be immediately taken into custody and the resident shall be informed. They will be given over without any delay and such people will not be permitted to embrace the Moslem religion.

10. The King further promises to co-operate with the Netherlands post in all cases and to oppose and prevent what might be undertaken to its disadvantage with all his might. No further permission will be given for the equipping and the sending to sea of pirates.

11. The Company promises that if any of its servants cause any annoyance, danger or harm to His Majesty's subjects, they will be fittingly punished and retribution and justice will be meted out to each person.

12. It is further concluded that this treaty will remain firm and constant as long as the mutual alliance between the Company. the King and his successors, lasts. The words of this treaty will convey its force and validity and all that has been agreed and concluded in this treaty shall be maintained and observed sin- 
cerely. The King promises this as well as the Company.

13. Lastly the King promises to publicise this contract throughout his entire kingdom in the same way as former treaties.

Contracted in the kingdom of Perak in the balai of the recently deceased king on the island Indra Sakti, 17 October in the year after Christ's birth 1765 or in the Moslem year 1179. the 29th day of the month Rabi al-akhir in the presence of the Raja Bendahara, the the Orang Kaya Besar, the Temenggong, and other nobles.

\section{Perjanjian, 20 Disember 1773}

Contract and indissoluble contract between Paduka Sirie Sulthan Alaidin Mantsur Iskandar Moeda Chaliphatur Rahim [Paduka Sri Sultan Alauddin Mansur Iskandar Muda Khalifatu'r Rahim] King of Perak and Anthony Abraham Werndly. merchant and fiscal at Melaka as well as delegate and envoy to that court on behalf of the Netherlands Patented East India Company.

This treaty resembles that of 1765 in all respects except for articles 3 and 9 . Article 3 reads:

This Company promises to pay His Majesty 32 round Spanish reals only for each bahara or three pikul of $375 \mathrm{lbs}$.

Article 9 is similar to the former one except that the Company also promised to give over any of Sultan Alauddin's subjects if they sought refuge with the Company. The conclusion reads:

Contracted in the kingdom of Perak in the balai of His Majesty on the large island [i.e., Pulau Besar] in the year of Muhammad 1187, the 5th day of the month Syawal on Monday in the morning, and in the year after the birth of Jesus Christ 1773, 20th December, in the presence of His Majesty, Raja Bendahara, and all the other nobles. 


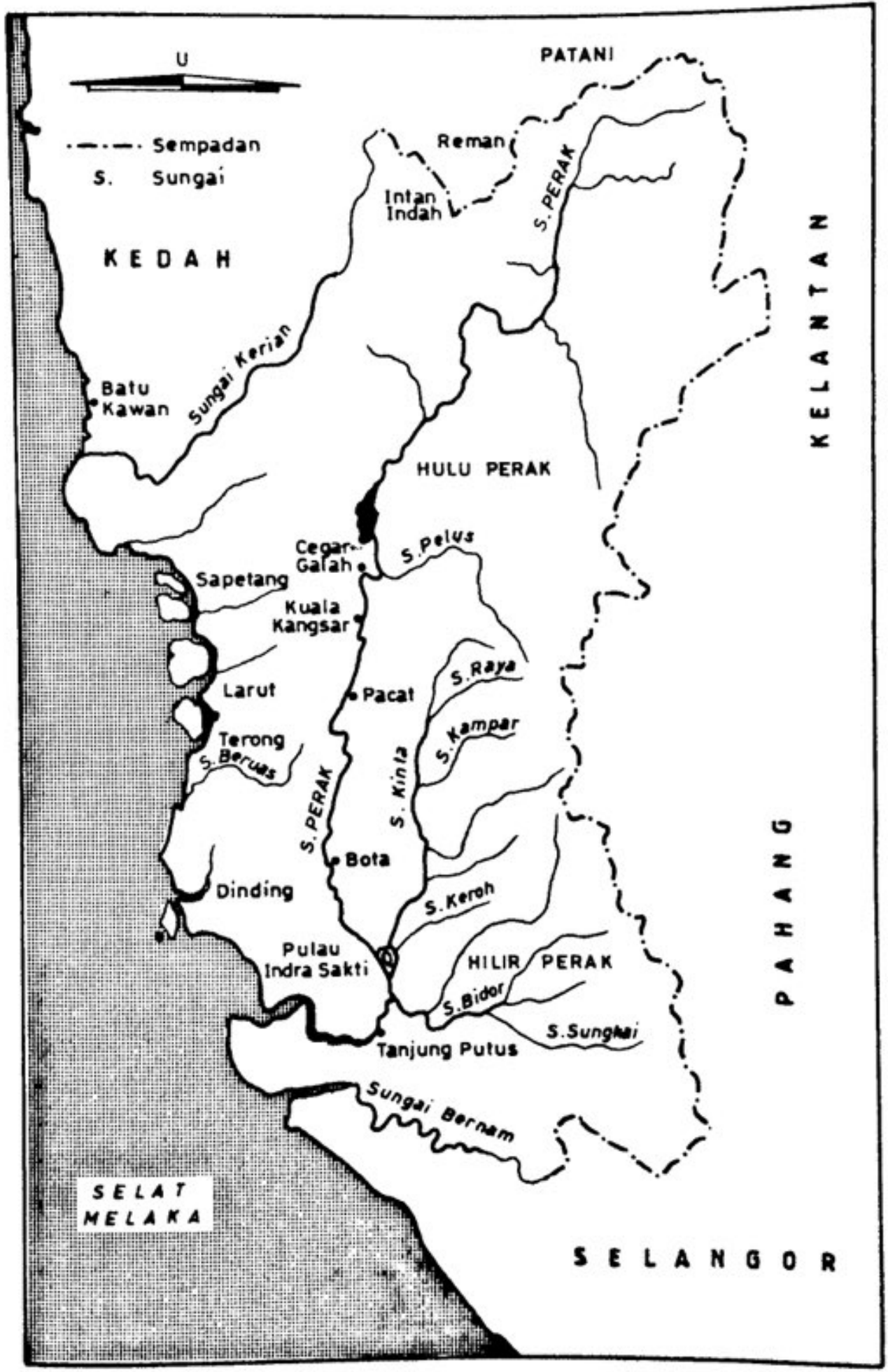

Peta 1: Kawasan Hulu dan Hilir Perak Dalam Abad Ke-18 


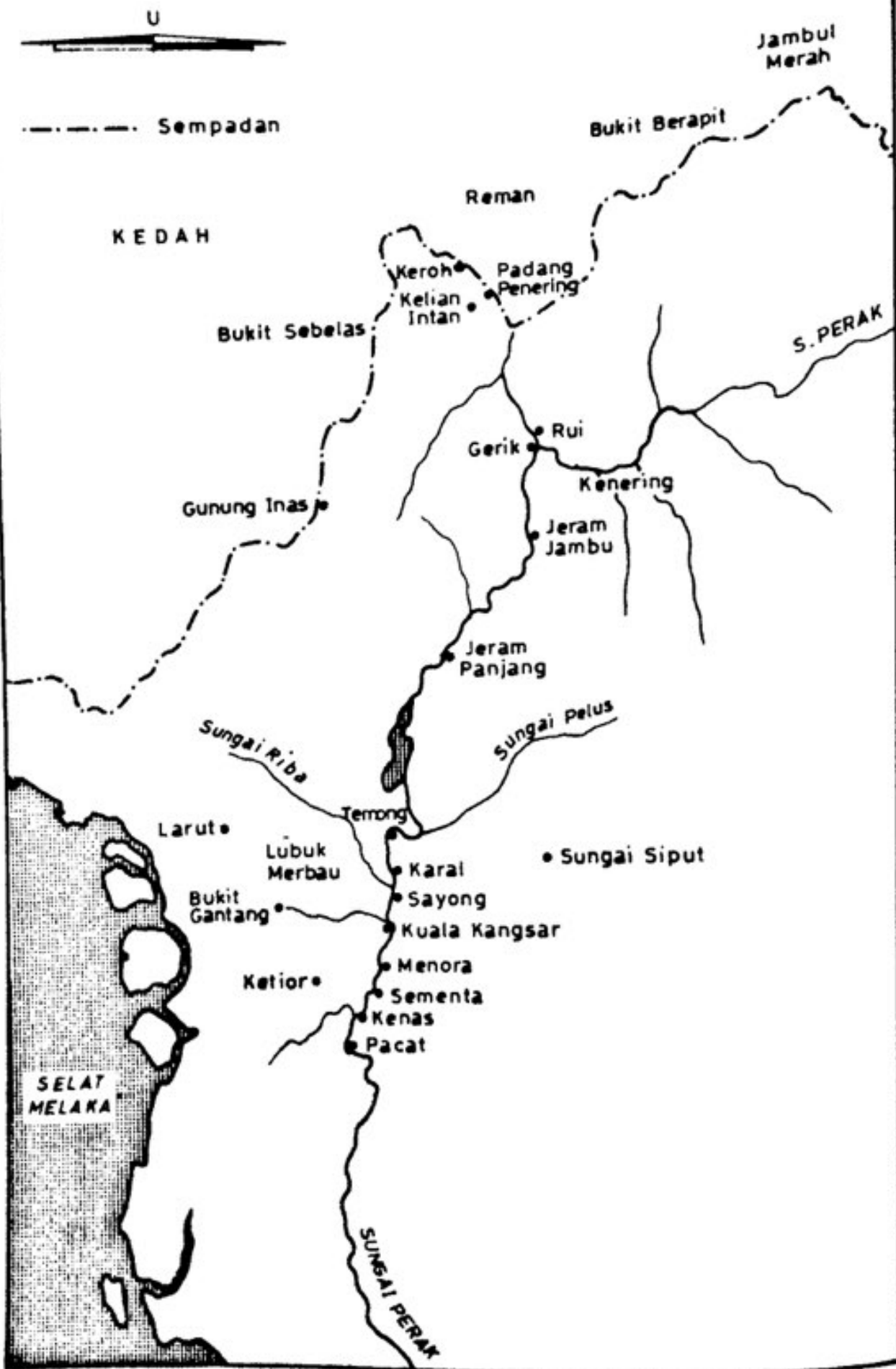

Peta 2: Kawasan utama melombong bijih di bahagian Hulu Perak pada abad ke-18. Menurut laporan Belanda tahun 1768. 


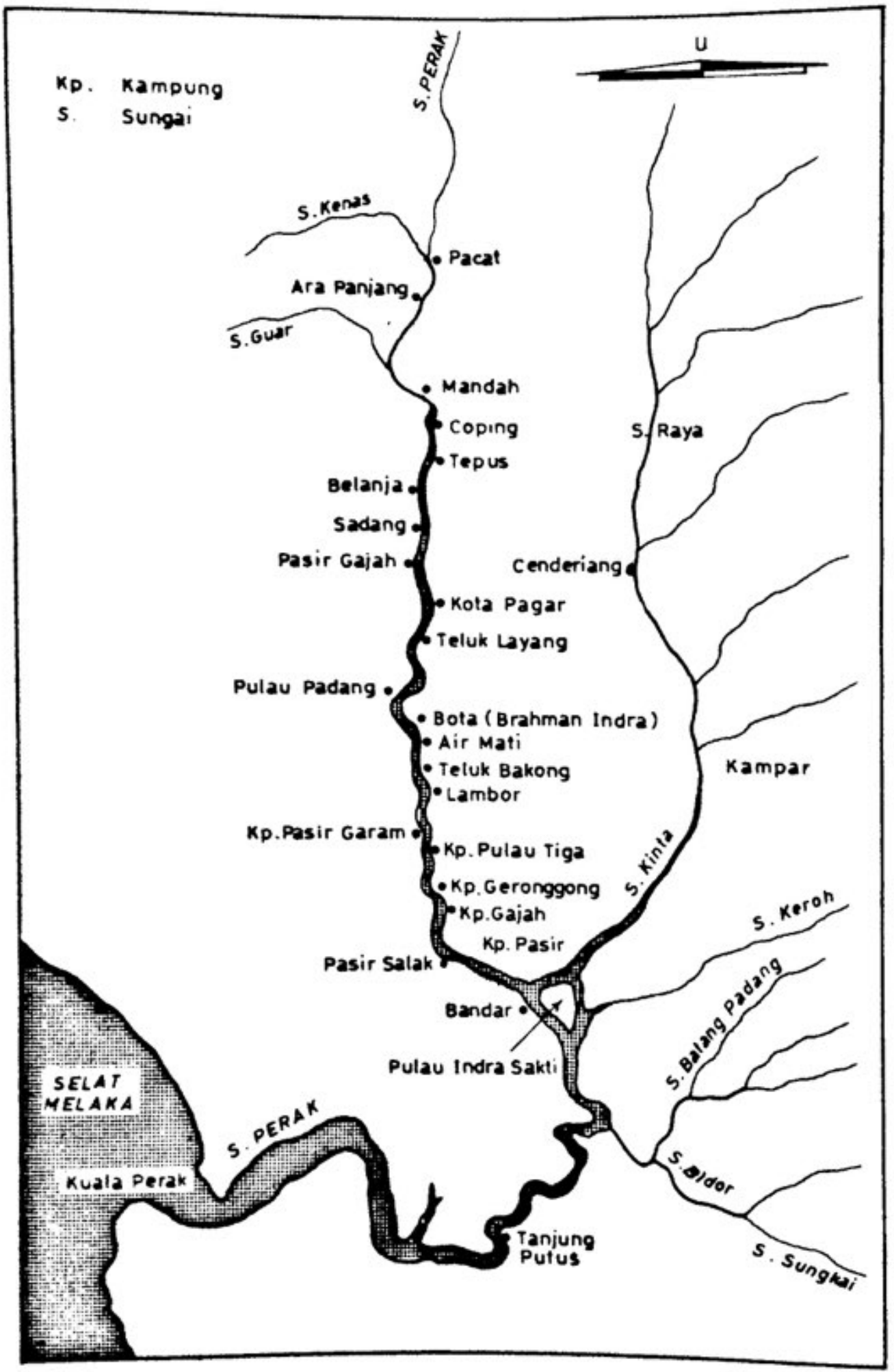

Peta 3: Kawasan utama melombong bijih di bahagian Hilir Perak pada abad ke-18. Menurut laporan Belanda tahun 1768. 